\title{
Effect of temperature on the reproduction and development of Trichogramma buesi (Hymenoptera: Trichogrammatidae)
}

\author{
Sergey Ya. REZNiK, Natalia D. VOINOViCH and Nina P. VAGHiNA
}

Zoological Institute, Russian Academy of Sciences, 199034 St. Petersburg, Russia; e-mail: sreznik@zin.ru

Key words. Temperature, Trichogramma, development, reproduction, pre-oviposition period, fecundity

\begin{abstract}
At emergence females of Trichogramma had a lot of mature eggs in their ovaries, but some delayed parasitization or refused to parasitize a laboratory host. The effect of constant and alternating temperatures on the percentage of Trichogramma buesi females parasitizing Sitotroga cerealella eggs and the duration of the pre-parasitization period were investigated. The temperature dependencies of the rate of preimaginal development, pre-emergence survival, number of eggs laid daily, and total lifetime fecundity were also determined. As the temperature was increased from 12 to $35^{\circ} \mathrm{C}$, the median pre-oviposition period decreased from 5 days to $3 \mathrm{~h}$, with maximum values of 24 and 1.5 days, respectively. The rate of induction of parasitization (reciprocal of duration of the pre-parasitization period of the females that parasitized) increased with temperature like the rate of preimaginal development and average number of eggs laid daily by a parasitizing female. Total cumulative percentage of parasitizing females reached a maximum (ca $60 \%$ ) at temperatures of $25-30^{\circ} \mathrm{C}$, while at 12 and $35^{\circ} \mathrm{C}$, respectively, 25 and $50 \%$ of females parasitized the $S$. cerealella eggs. Average lifetime fecundity and pre-emergence survival showed a similar dependence on temperature. The influence of the thermorhythm $\left(25^{\circ} \mathrm{C}\right.$ for $4 \mathrm{~h}$ and $15^{\circ} \mathrm{C}$ for $\left.20 \mathrm{~h}\right)$ was strongly dependent on its position within the photoperiod. When thermophase coincided with photophase, the percentage of females that parasitized was close to that recorded at a constant temperature of $25^{\circ} \mathrm{C}$. But when the high temperature pulse coincided with the dark period, the percentage of parasitizing females was the same as at $15^{\circ} \mathrm{C}$. Thus, the temperature dependence of ethogenesis (supposedly, an increase in motivation to parasitize or search for a host) in Trichogramma females was similar to that of morphogenesis, although the reaction to alternating temperatures may have been complicated by interaction with the light : dark regime.
\end{abstract}

\section{INTRODUCTION}

Temperature is one of the most important environmental factors influencing insect physiology and behaviour (Ratte, 1985). The various manifestations of this influence can be roughly classified into three groups according to the reaction pattern, effect on stability, and certain other characteristics.

First, temperature influences the rate of insect growth and development. This dependence is usually linear except at the upper extreme where the rate decreases and the response curve is markedly asymmetrical (Ratte, 1985; Honěk \& Kocourek, 1990; Brière et al., 1999). The rate of development under a thermoperiod is usually equal or slightly higher than that at its mean effective temperature (Beck, 1983; Ratte, 1985). The intensity of various behavioural and physiological processes (e.g. speed of movement, instantaneous rate of oviposition etc.) depend on temperature in a similar way and are usually rapid and reversible, with alternating temperatures causing similar changes in insect activity.

Second, numerous parameters (survival, lifetime fecundity, etc.) reach a maximum at a certain optimal temperature and more or less symmetrically decrease toward both lower and upper limits of tolerance, moderate thermoperiods produce somewhat "better" results than the mean temperatures (Beck, 1983; Ratte, 1985).

Third, temperature may serve as a key factor regulating seasonal or daily cycles and thus indirectly influence various aspects of insect biology (Tauber et al., 1986;
Zaslavski, 1988; Danks, 2003). In this case, temperature often interacts with other environmental cues, particularly photoperiod. The thermoperiod could be a very strong signal, incommensurable with the mean temperature. Reaction to a key factor often produces a stable (if not irreversible) ultimate effect (e.g., diapause or active development).

In reality, however, different types of thermal influence often interact and their effects can only be separated experimentally (Ratte, 1985). This study was done on an egg parasitoid Trichogramma buesi Voegele (= T. brassicae Voegele) (Hymenoptera: Trichogrammatidae), which is not only widely used for the biological control of lepidopteran pests (Mertz et al., 1995; Smith, 1996) but also a convenient model for various biological studies. In particular females of $T$. buesi, like those of many other Trichogramma species, refuse to parasitize eggs of laboratory hosts or delay parasitization for a period of up to 10-12 days (Pak \& van Heiningen, 1985; Pavlik, 1993; Hoffmann et al., 2001; Bennett et al., 2002; Hansen \& Jensen, 2002: Reznik \& Vaghina, 2007a, b; see Reznik et al., 2001, 2003 for more references). The results of an earlier study on Trichogramma principium Sug. et Sor. (Reznik \& Vaghina, 2006) suggest that the duration of the pre-oviposition period is shorter at high temperatures. It is well known that in synovigenic insects temperature may affect the duration of the pre-reproductive period by influencing the rate of oogenesis (Ratte, 1985; Brière et al., 1999). Maximal lifetime fecundity of Trichogramma 
females ranges up to 100 eggs, while emerging females have 20-25 eggs (Pak \& Oatman, 1982; Pavlik, 1992; Pratissoli \& Parra, 2000; Reznik et al., 2001, 2003; see also the results of the present study). Thus, its ovigeny index is ca 0.25. Dissections show that the Trichogramma females that delay parasitization have a lot of mature eggs in their ovaries, but their behaviour is blocked at the stage of arrestment and host recognition (Pak \& van Heiningen, 1985; Pavlik, 1993; Schmidt, 1994; Reznik et al., 2001, 2003; Reznik \& Vaghina, 2007b). Hence, temperature influences the duration of the pre-parasitization period by accelerating ethogenesis (age-related changes in behaviour, most probably, increase the motivation to parasitize or broaden host range), rather than by accelerating oogenesis. Generally speaking, it is likely that temperature will affect when a female will parasitize a low quality host, as insect host specificity often widens with time (Withers et al., 2000) and "internal time" passes more rapidly at high temperatures. However, the thermal dependence of ethogenesis, as far as we know, has not been investigated in detail.

In most of the earlier studies on the effect of temperature on the percentage of Trichogramma females that parasitized, the observation period was rather short, which prevented the separation of females that totally refuse to parasitize from those that only delayed parasitization (see Discussion for references). However, by analogy with morphogenesis, it is likely that: (1) the "final result" (total percentage of parasitizing females) could reach a maximum near the middle of the tolerance zone and have approximately the same optimal temperature as preimaginal survival or lifetime fecundity, (2) the "intensity" (rate of induction of parasitization, i.e. the reciprocal of duration of the pre-parasitization period of females that parasitized) could increase with temperature like the rate of development and (3) moderate thermoperiods could slightly increase both the percentage of parasitizing females and the rate of induction of parasitization. The present study was carried out to test these hypotheses. In addition, we aimed to determine if the temperature dependence of the pre-parasitization period revealed in our earlier study (Reznik \& Vaghina, 2006) is a unique feature of $T$. principium or of all Trichogramma species. For this purpose, the influence of constant and alternating temperatures on the induction of parasitization and certain other biological characteristics of $T$. buesi were investigated. In particular, pre-emergence survival, total lifetime fecundity, duration of preimaginal development and the number of eggs laid daily were estimated.

\section{MATERIAL AND METHODS}

\section{Insects and general methods}

Experiments were conducted with a strain of $T$. buesi collected in Saratov province, Russia $\left(\mathrm{ca} 52^{\circ} \mathrm{N}\right)$ from Noctuidae eggs and then reared on the eggs of the Angoumois grain moth, Sitotroga cerealella Oliv. (Lepidoptera: Gelechiidae), for more than 100 generations. The species was identified by Dr. E.S Sugonyaev (Zoological Institute, St. Petersburg, Russia). To start the experiment, a paper card with several thousand $S$. cerealella eggs glued to it was placed in a test tube with ca 1000
T. buesi adults for 2-4 h after which it was removed from the tube and kept at $20^{\circ} \mathrm{C}$ under a photoperiod of $18 \mathrm{~L}: 6 \mathrm{D}$. Under these conditions, most $T$. buesi adults emerged shortly after the light came on (Reznik et al., 1998). The first adults to emerge were killed shortly before the light was turned off, ensuring that $4 \mathrm{~h}$ after the light came on the next day the tube contained evenaged wasps, which were used in the experiments. All experiments were conducted at the same photoperiod (12L : 12D) and humidity (ca 75\%) but at different temperatures. In our (unpubl.) preliminary tests, T. buesi females did not parasitize eggs at $10^{\circ} \mathrm{C}$ and $40^{\circ} \mathrm{C}$. Same or similar results were earlier obtained for other Trichogramma species (see Discussion for references). Thus, we restricted this study to the temperature range 12 to $35^{\circ} \mathrm{C}$.

\section{First experiment}

In the first experiment, the influence of constant temperatures on the duration of preimaginal development was investigated. For each replicate of this experiment, a block of 6 paper cards with 300-400 grain moth eggs glued on each card was exposed for $2 \mathrm{~h}$ to parasitization by ca $500 \mathrm{~T}$. buesi females at $20^{\circ} \mathrm{C}$. Then these cards were each placed in a test tube and incubated at either $12,15,20,25,30$ or $35^{\circ} \mathrm{C}$. As was noted above, most Trichogramma adults emerge during the first hours of the photophase. Hence, emerged adults were counted daily $6 \mathrm{~h}$ after the light came on and this was taken to be the time of their emergence. The duration of preimaginal development was measured as the period of time from oviposition to adult emergence. There were four replicates of this experiment. Because of the rhythmic emergence of adults, circadian time of oviposition could influence the total duration of Trichogramma preimaginal development (Doyon \& Boivin, 2005). That is why, in two replicates parasitization occurred just after the light came on, and in two other replicates, just before the light was switched off (i.e. $10 \mathrm{~h}$ later). In total, 6,591 adults emerged.

\section{Second experiment}

The aim of the second experiment was to estimate the effect of temperature on pre-emergence survival. In this experiment, $T$. buesi females were individually placed in small $(8 \times 45 \mathrm{~mm})$ test tubes. A paper card with 50-60 S. cerealella eggs was placed in each tube and all females were allowed to parasitize host eggs for $24 \mathrm{~h}$ at $30^{\circ} \mathrm{C}$ (as was shown by pilot tests and supported by the results of the present study, at this temperature the majority of females started to parasitize eggs on the first day of coming into contact with the host). Then the paper cards with host eggs were immediately taken from the tubes and randomly divided between six treatments, which involved keeping the eggs at either $12,15,20,25,30$ or $35^{\circ} \mathrm{C}$. When the adults ceased to emerge in a given treatment, the darkened host eggs were inspected. As $S$. cerealella eggs are rather small, T. buesi females usually lay only one egg in each host egg. Hence, the number of host eggs with emergence holes was taken to be the number of emerged wasps. Darkened host eggs without emergence holes were dissected. Such eggs contained dead adults, pupae or prepupae. The total number of emerged adults, dead adults, pupae and prepupae was recorded for each female and is its fecundity. In this experiment, only data for females that parasitized at least one host egg were included in the analysis. Females that failed to parasitize were discarded.

Host eggs parasitized by Trichogramma darken at the time of parasitoid prepupal moult (Jarjees \& Merritt, 2002). Thus, the percentage survival from the prepupal to the adult stage and the percentage of adults that emerged (did not die inside the chorion of the host egg) were calculated for each female used in this experiment. As indicated above, the cards with parasitized host 
TABLE 1. Effect of alternating and constant temperatures on the percentage of Trichogramma buesi females parasitizing, their fecundity and number of mature eggs in their ovaries.

\begin{tabular}{|c|c|c|c|c|c|}
\hline \multirow{2}{*}{\multicolumn{2}{|c|}{ Variables }} & \multicolumn{4}{|c|}{ Treatment \# } \\
\hline & & 1 & 2 & 3 & 4 \\
\hline \multirow{3}{*}{$\begin{array}{l}\text { Temperature regiments } \\
\text { (in all treatments the } \\
\text { photoperiod was } \\
12 \mathrm{~L}: 12 \mathrm{D} \text { ) }\end{array}$} & \multirow[b]{2}{*}{ 1st-2nd day of experiment } & \multicolumn{2}{|c|}{ Thermoperiod of $15 / 25^{\circ} \mathrm{C}$} & \multirow[b]{2}{*}{$\begin{array}{l}\text { Constant } \\
\text { temperature } \\
\text { of } 15^{\circ} \mathrm{C}\end{array}$} & \multirow[b]{2}{*}{$\begin{array}{l}\text { Constant } \\
\text { temperature } \\
\text { of } 25^{\circ} \mathrm{C}\end{array}$} \\
\hline & & $\begin{array}{c}\text { Thermophase during } \\
\text { the first } 4 \mathrm{~h} \text { of the } \\
\text { photophase }\end{array}$ & $\begin{array}{l}\text { Thermophase during } \\
\text { the first } 4 \mathrm{~h} \text { of the } \\
\text { scotophase }\end{array}$ & & \\
\hline & 3rd-4th day of experiment & \multicolumn{4}{|c|}{ Constant temperature of $15^{\circ} \mathrm{C}$} \\
\hline \multirow{2}{*}{$\begin{array}{l}\text { Parasitizing females } \\
\text { (percentage of surviving } \\
\text { females) }\end{array}$} & 1st-2nd day of experiment $*$ & 54 a (47-61) & $11 \mathrm{~b}(2-15)$ & $15 \mathrm{~b}(10-20)$ & 63 a (59-66) \\
\hline & 3 rd -4 th day of experiment $*$ & 46 a $(39-56)$ & $17 \mathrm{c}(13-20)$ & $30 \mathrm{~b}(24-36)$ & 53 a (44-59) \\
\hline \multirow{3}{*}{$\begin{array}{l}\text { Fecundity } \\
\text { of parasitizing } \\
\text { females }\end{array}$} & 1 st -2 nd day of experiment $* *$ & $31.5 \pm 9.3 \mathrm{a}$ & $33.4 \pm 4.5 \mathrm{a}$ & $30.3 \pm 8.8 \mathrm{a}$ & $39.8 \pm 4.8 \mathrm{~b}$ \\
\hline & $\begin{array}{l}\text { 3rd-4th day of experiment } \\
\text { (started to parasitize) } * *\end{array}$ & $25.7 \pm 9.4 \mathrm{a}$ & $23.1 \pm 7.6 \mathrm{a}$ & $24.6 \pm 7.6 \mathrm{a}$ & $21.6 \pm 7.3 \mathrm{a}$ \\
\hline & $\begin{array}{l}\text { 3rd-4th days of the experiment } \\
\text { (continued to parasitize)** }\end{array}$ & $6.3 \pm 4.8 \mathrm{a}$ & $6.5 \pm 4.1 \mathrm{a}$ & $7.7 \pm 3.9 \mathrm{a}$ & $8.2 \pm 5.7 \mathrm{a}$ \\
\hline \multirow{2}{*}{$\begin{array}{l}\text { Number of mature eggs } \\
\text { in ovaries on the } 5 \text { th day } \\
\text { of the experiment }\end{array}$} & $\begin{array}{c}\text { Females that parasitized for } \\
\text { more than } 2 \text { days* }\end{array}$ & 2 a $(1-4)$ & 3 a $(2-5)$ & 3 a $(2-4)$ & 2 a $(1-4)$ \\
\hline & $\begin{array}{l}\text { Females that did not } \\
\text { parasitize** }\end{array}$ & $36.9 \pm 8.3 \mathrm{a}$ & $36.7 \pm 5.6 \mathrm{a}$ & $34.8 \pm 6.8 \mathrm{a}$ & $33.1 \pm 4.2 \mathrm{a}$ \\
\hline
\end{tabular}

* Medians and (quartiles) are given. Values with the same letter in the same row are not significantly different (p $>0.05$, Tukey HSD test of ranked data).

** Means \pm SD are given. Values with the same letter in the same row are not significantly different $(p>0.05$, Tukey HSD test).

eggs were randomly distributed among treatments. Hence, we presumed that there was no significant difference in the mean number of parasitized host eggs across the temperature regimes. Thus, the temperature dependence of the mean number of darkened host eggs per female (if any) could be used as an indirect estimate of the effect of temperature on survival to the prepupal stage. In this experiment, results for 100-120 parasitizing females $(3,000-4,000$ parasitized host eggs) per treatment (temperature) were recorded. In most low temperature treatments $\left(12^{\circ} \mathrm{C}\right)$ some host eggs with living diapausing prepupae were found, which were included in the total of darkened eggs, but were discarded when the percentage of parasitoids reaching the next stage in development was calculated.

\section{Third experiment}

The aim of the third experiment was to estimate the effect of various constant temperatures on host parasitization. For this experiment, recently emerged $T$. buesi females were individually placed in small glass test tubes that contained honey $(50 \%$ water solution streaked inside the tube) as a carbohydrate food source and were kept at $20^{\circ} \mathrm{C}$. At the beginning of the next photophase (when females were ca 1-day-old) the experiment was started, i.e. a small paper card with 50-60 S. cerealella eggs was placed in each tube and the tubes were randomly divided between six treatments, which were kept at $12,15,20,25,30$ or $35^{\circ} \mathrm{C}$. The paper cards with host eggs were periodically taken from the tubes and each living female received a new card. During the $1^{\text {st }}$ day of the experiment, paper cards with host eggs were replaced 3, 6, 9 or $12 \mathrm{~h}$ after the light came on. During the $2^{\text {nd }}$ and $3^{\text {rd }}$ days, cards were replaced just after the light came on, and 6 and $12 \mathrm{~h}$ after the light came on. Then, host eggs were replaced $9 \mathrm{~h}$ after the light came on, on day $4,5,6,8,10,12,16$ and thereafter every $4^{\text {th }}$ day until the female died. A new drop of honey solution was provided to all surviving females every 5-7 days.

The cards with host eggs taken from the tubes were kept at $25^{\circ} \mathrm{C}$. In 6-7 days, the parasitized host eggs darkened and the number of eggs parasitized during each exposure (period between host replacements) was counted and taken to be the number of eggs laid by a Trichogramma. There were ten replicates of the $3^{\text {rd }}$ experiment, each of which included 150-180 females (25-30 per treatment). The survival time for each female was recorded. For each replicate of each treatment, the total percentage of parasitizing females (i.e. those that parasitized at least one host) was calculated. For each parasitizing female, the total number of hosts it parasitized and the duration of the pre-parasitization period (i.e. the period of time spent with hosts before the first host was parasitized) were determined. Time of parasitizing the first host was taken to be the middle of the corresponding exposure period.

\section{Fourth experiment}

This experiment was aimed at evaluating the effect of thermoperiods on parasitization. As in the previous test, T. buesi females were individually placed in test tubes with carbohydrate food and host eggs. The $4^{\text {th }}$ experiment included four treatments (Table 1). In the $1^{\text {st }}$ and the $2^{\text {nd }}$ treatments, females were kept for $48 \mathrm{~h}$ at a particular thermoperiod $\left(25^{\circ} \mathrm{C}\right.$ for $4 \mathrm{~h}$ and $15^{\circ} \mathrm{C}$ for 20 h) and photoperiod $(12 \mathrm{~L}: 12 \mathrm{D})$, but in the $1^{\text {st }}$ treatment, the beginning of thermophase coincided with the moment the light came on and in the $2^{\text {nd }}$ treatment when it went off. In the $3^{\text {rd }}$ and $4^{\text {th }}$ treatments, females were kept for $48 \mathrm{~h}$ at the same photoperiod and a constant temperature of $15^{\circ} \mathrm{C}$ or $25^{\circ} \mathrm{C}$, respectively. Forty eight hours after the beginning of the experiment, cards with host eggs were replaced and all females were kept at $15^{\circ} \mathrm{C}$ for another $48 \mathrm{~h}$. Then all living females were dissected to count the number of mature eggs in their ovaries.

There were eight replicates of this experiment each included 100 females ( 25 per treatment). For each replicate of each treatment, the percentage of parasitizing females was separately determined for each $48 \mathrm{~h}$ period of exposure. For each female that survived to the end of the experiment, the number of host parasitized during each exposure and the number of mature eggs in their ovaries at dissection, were recorded. 


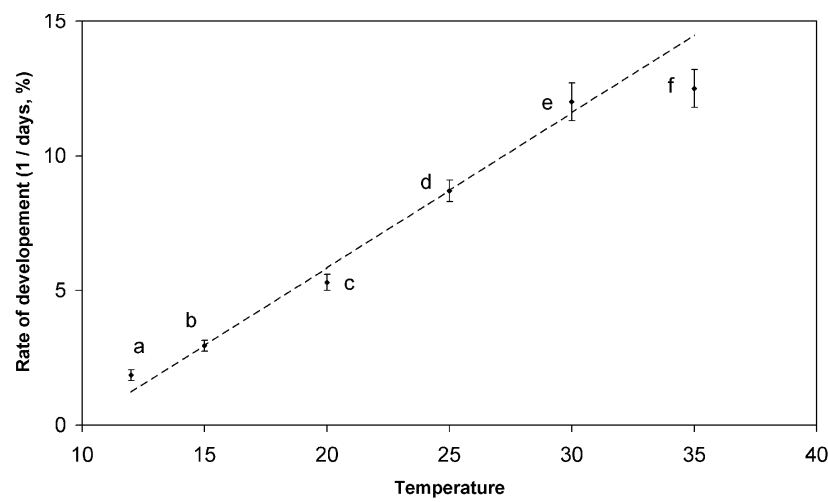

Fig. 1. The effect of temperature on the rate of development of Trichogramma buesi. Means \pm SD are given. Dashed line linear regression: $\mathrm{y}=0.576 \mathrm{x}-5.675, \mathrm{r}=0.988, \mathrm{n}=5627$. Symbols with different letters are significantly different $(\mathrm{p}<$ 0.05 , Tukey test of ranked data).

\section{Statistical treatment}

For percentage of ovipositing females, each replicate was considered an experimental unit. For pre-emergence survival, progeny of one parasitizing female was an experimental unit. For other parameters, each individual Trichogramma female was an experimental unit. The rate of development, number of hosts parasitized by ovipositing females and number of mature eggs in non-ovipositing females were normally distributed and thus analysed using regression and the Tukey HSD test. Other variables were not normally distributed and were analysed using Spearman rank correlation and ranked data in the ANOVA and Tukey HSD test. In the text and figures, mean \pm SD are used as descriptive statistics for normally distributed data, for other variables medians and quartiles are given.
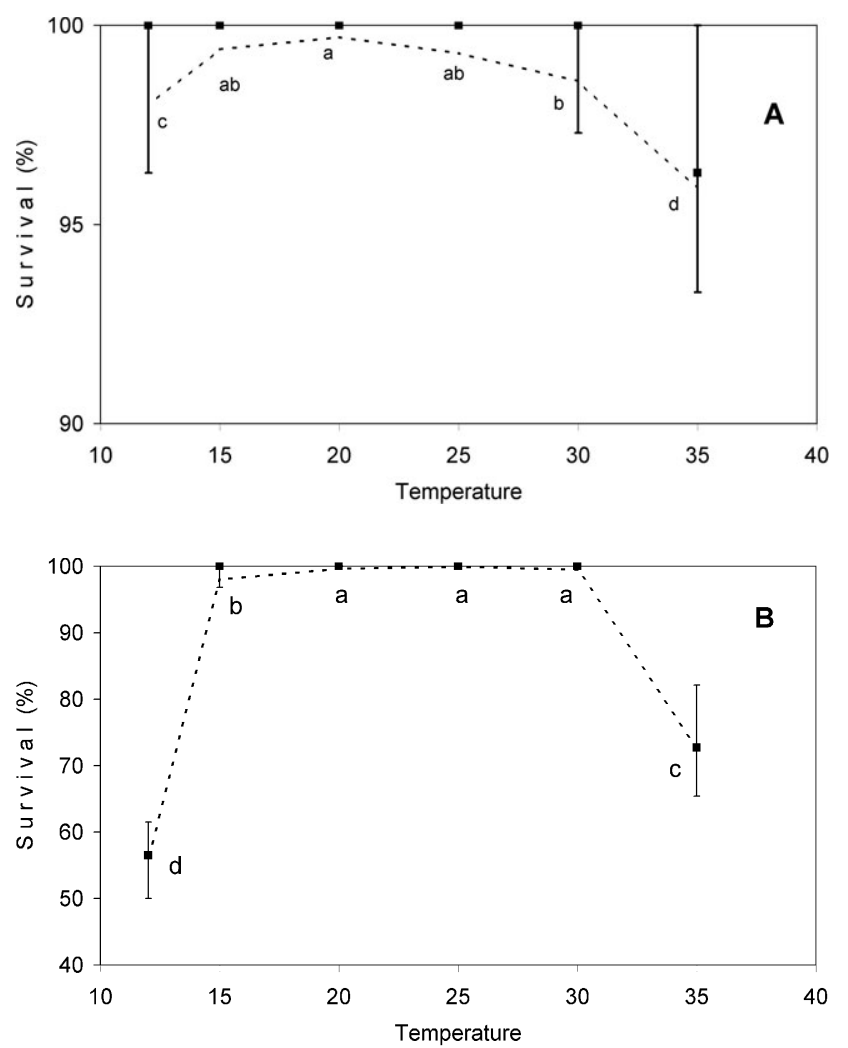

\section{RESULTS}

\section{First experiment}

Preliminary treatment (two way ANOVA) showed that the period of time from oviposition to adult emergence significantly $(p<0.001)$ depended on temperature, but not on circadian time of oviposition $(\mathrm{p}>0.5)$. Thus, data from all the replicates were pooled for the final treatment. As expected, the rate of development increased with temperature, this dependence is accurately described by linear regression $(r=0.980, \mathrm{SE}$ of estimate $=0.77)$. Note that at $35^{\circ} \mathrm{C}$ the rate of development was only slightly higher than at $30^{\circ} \mathrm{C}$ (Fig. 1). When data for the extreme temperature of $35^{\circ} \mathrm{C}$ were excluded, the correlation became stronger $(\mathrm{r}=0.988, \mathrm{SE}=0.54)$, the lower developmental threshold was $9.8^{\circ} \mathrm{C}$ and the sum of effective temperatures - 174 degree-days.

\section{Second experiment}

Survival from prepupal to adult stage (Fig. 2A) was $100 \%$ of the progeny of most females over a wide range of temperatures from 15 to $25^{\circ} \mathrm{C}$ and slightly but significantly decreased at $12^{\circ} \mathrm{C}$ and $30-35^{\circ} \mathrm{C}$. Percentage of adults that emerged successfully (Fig. 2B) showed a similar pattern of dependence, except at $12^{\circ} \mathrm{C}$ when there was a pronounced decrease compared to that observed at $35^{\circ} \mathrm{C}$. The number of darkened host eggs per parasitizing female (an estimate of larval survival to the prepupal stage) also markedly decreased with temperature within the range of $25-35^{\circ} \mathrm{C}$, but at $12-15^{\circ} \mathrm{C}$ it was only slightly lower than that at the optimal temperature (Fig. 2C). Although pairwise comparisons showed that the number of darkened host eggs at $25^{\circ} \mathrm{C}$ was not significantly

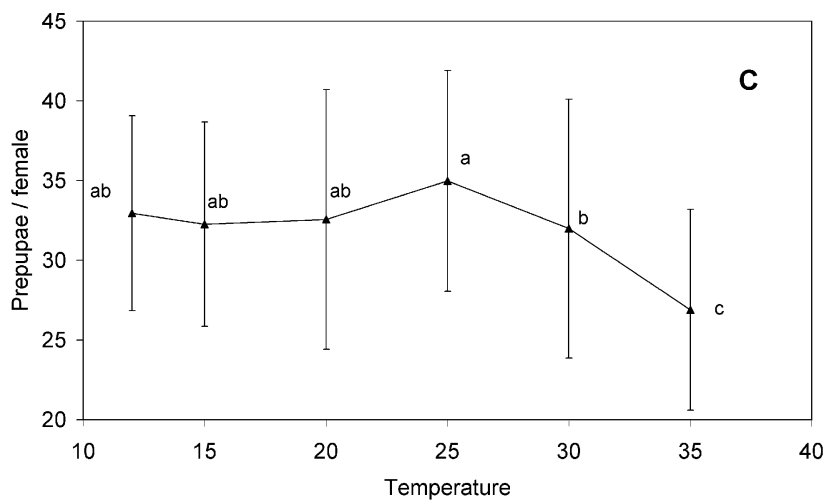

Fig. 2. The effect of temperature on pre-emergence survival of Trichogramma buesi. A - percentage survival from prepupal to adult stage; B - percentage of adults that emerged successfully; $\mathrm{C}$ - larval survival to the prepupal stage, estimated using the number of darkened host eggs per parasitizing female. A and B - symbols show medians and quartiles for progeny of individual females, dotted line indicates percentages calculated for the total progeny of all females; $\mathrm{C}-$ means $\pm \mathrm{SD}$. Same symbols with different letters are significantly different $(p<0.05$, Tukey test, A and B - data were ranked before the test). 


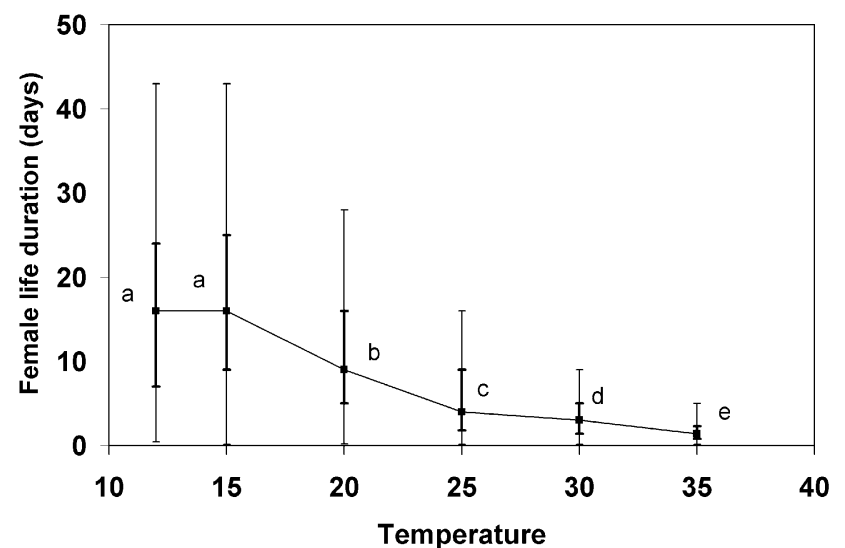

Fig. 3. The effect of temperature on the lifespan of female Trichogramma buesi. Medians, quartiles and ranges are given. Symbols with different letters are significantly different $(\mathrm{p}<$ 0.05 , Tukey test of ranked data).

higher than at lower temperatures, the pooled data for $12-20^{\circ} \mathrm{C}(32.5 \pm 7.0 \mathrm{eggs} /$ female $)$ were significantly $(\mathrm{p}<$ $0.01)$ different from the data for $25^{\circ} \mathrm{C}(35.0 \pm 6.9$ eggs/female).

\section{Third experiment}

In the laboratory, $T$. buesi females survive for a rather long time. As expected, maximum and median adult lifespan gradually decreased with increasing temperature (Fig. 3). The average duration of the pre-parasitization period (Fig. 4, left axis) was extremely variable but also significantly decreased with increasing temperature. Note that at all temperatures, the maximum duration of the preparasitization period was only slightly shorter than the maximum survival time (comp. Figs 3 and 4), i.e. some females delayed parasitization almost up to death. The rate of induction of parasitization (reciprocal of the duration of the pre-parasitization period) obviously increased with temperature (Spearman rank correlation, $r=0.63$ ) although the trend in this response was not clear because of high variation and skewed distribution of the data (Fig. 4 , right axis).

At all temperatures, a significant percentage of females did not parasitize hosts. The maximum cumulative percentage of parasitizing females was recorded at $25-30^{\circ} \mathrm{C}$ (Fig. 5), although pairwise comparisons of ranked data revealed a significant decrease only at $12-20^{\circ} \mathrm{C}$. The total lifetime fecundity (Fig. 6) had the same maximum, but somewhat more pronounced, with a significant decrease both at $12-20^{\circ} \mathrm{C}$ and $35^{\circ} \mathrm{C}$.

The mean daily fecundity gradually increased with temperature (Spearman rank correlation, $r=0.74$ ). As it was not normally distributed, a linear regression was not calculated, but the graph (Fig. 7) indicates a lower threshold of approximately $11^{\circ} \mathrm{C}$.

\section{Fourth experiment}

The last experiment (Table 1) gave very clear results. When the $4 \mathrm{~h}$ long thermophase coincided with the photophase ( $1^{\text {st }}$ treatment), the percentage of females that started to parasitize within $48 \mathrm{~h}$ was not significantly lower than that at a constant temperature of $25^{\circ} \mathrm{C}\left(4^{\text {th }}\right.$

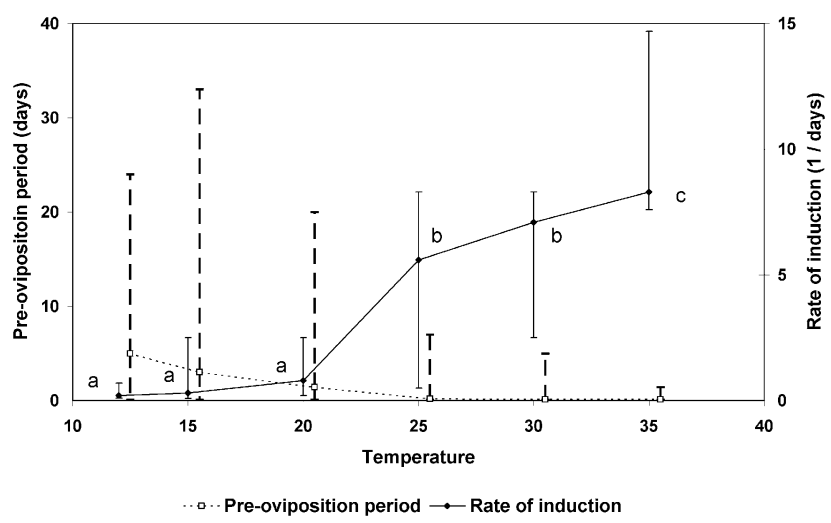

Fig. 4. The effect of temperature on the rate of induction of parasitization and duration of preoviposition period of the Trichogramma buesi females that parasitized hosts. For the preoviposition period, medians and ranges are given; for the rate of induction, medians and quartiles are given. To avoid overlap, symbols are slightly shifted along the horizontal axis. Symbols with different letters are significantly different $(p<0.05$, Tukey test of ranked data).

treatment). But when the same high temperature pulse was given in the dark period ( $2^{\text {nd }}$ treatment), the percentage of parasitizing females was practically the same as at $15^{\circ} \mathrm{C}\left(3^{\text {rd }}\right.$ treatment $)$.

Moreover, this sharp difference between treatments persisted during the 3rd-4th days of the experiment, when all females were kept at $15^{\circ} \mathrm{C}$. The reason for this was that most of the females that parasitized during the first two days of the experiment continued to do so during the last two days. ANOVA test of ranked data showed that the percentage of such females among those parasitizing during the first two days was not significantly dependent on treatment $(p=0.25)$, median and quartiles for pooled data of all treatments constituted $80 \%$ (64-90\%). The percentage of the wasps that did not parasitize during the first two days of the test, but started to parasitize later was much lower: $10 \%(0-23 \%)$, and also independent of treatment $(\mathrm{p}=0.53)$.

The fecundity of parasitizing females differed in the different temperature regimes. At $25^{\circ} \mathrm{C}$ the number of hosts parasitized during 2 days was higher than at $15^{\circ} \mathrm{C}$, while the effect of a $4 \mathrm{~h}$ long high temperature pulse was not significant, independent of its position in the photoperiod. In addition, the difference in fecundity was not stable: during the 3rd-4th days of the experiment, when the temperature was the same, the fecundity was also similar in all treatments, although it markedly differed for females that just started to parasitize and in those that continued to parasitize.

Dissections at the end of this experiment showed that the number of mature eggs in the ovaries of parasitizing females was much lower than in those that did not parasitize during 4 days of contact with the host. Pairwise comparison of treatments did not reveal any significant difference. However, pooling the data of corresponding treatments $\left(1^{\text {st }}\right.$ and $2^{\text {nd }}$ vs. $3^{\text {rd }}$ and $\left.4^{\text {th }}\right)$ showed that in females that did not parasitize when subjected to a thermorhythm the mean number of mature eggs in their ova- 


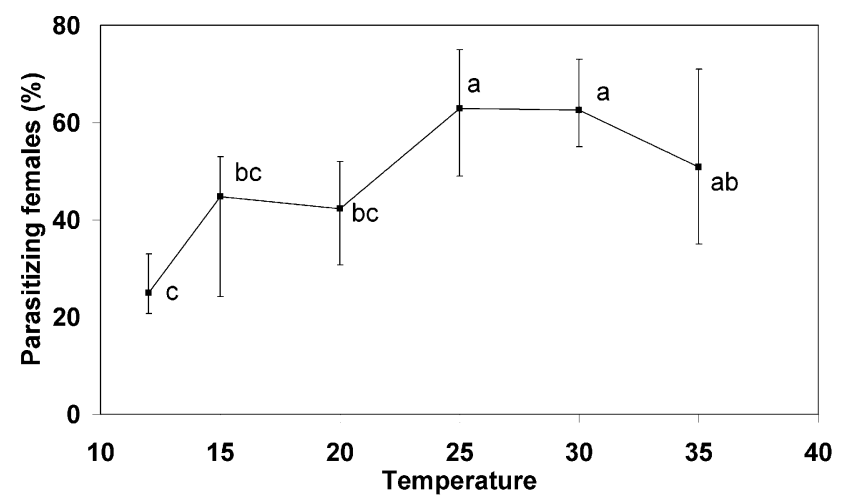

Fig. 5. The effect of temperature on the cumulative percentage of the Trichogramma buesi females that parasitized hosts. Medians and quartiles are given. Symbols with different letters are significantly different $(\mathrm{p}<0.05$, Tukey test of ranked data).

ries was slightly but significantly $(\mathrm{p}=0.03)$ higher than in those kept at a constant temperature of $15^{\circ} \mathrm{C}$ or $25^{\circ} \mathrm{C}$ (Table 1).

\section{DISCUSSION}

\section{Rate of development}

There are nonlinear models that approximate the observed relationships between temperature and insect development (Brière et al., 1999). However, in practice linear summation accurately describes the thermal influence on development over a wide range of temperatures in various insects (Rattte, 1985; Honěk \& Kocourek, 1990; Richards \& Villet, 2008), including insect parasitoids (e.g. Abe \& Tahara, 2003) and particularly Trichogramma species (Butler \& Lopez, 1980; Cônsoli \& Parra, 1995a; Hansen, 2000; Kalyebi et al., 2006; Foerster \& Foerster, 2009). This is clear from our data (Fig. 1). Note, however, that at $35^{\circ} \mathrm{C}$ the mean rate of development was much lower than that predicted by the linear regression. Hence, judging from this parameter, $35^{\circ} \mathrm{C}$ is supraoptimal for T. buesi. In less thermo-tolerant Trichogramma species, even a slight increase in duration of development was recorded at $34^{\circ} \mathrm{C}$ (Butler \& Lopez, 1980).

As far as we know, special experiments aimed at determining the thermal constants of $T$. buesi have not been conducted before. However, under natural conditions (Voegele et al., 1988) the lower threshold is approximately $10^{\circ} \mathrm{C}$ and the sum of effective temperatures 126-150 degree-days, which are similar to those obtained in our study and typical of Trichogramma: in other species, the lower threshold ranges from $8^{\circ} \mathrm{C}$ to $13^{\circ} \mathrm{C}$ and degree-day accumulation from 130 to 190 (Butler \& Lopez, 1980; Harrison et al., 1985; Cônsoli \& Parra, 1995a; Hansen, 2000; Kalyebi et al., 2006; Foerster \& Foerster, 2009).

\section{Pre-emergence survival and female longevity}

The effect of temperature on survival from the prepupa to adult stage and percentage of adults that emerged successfully revealed in this study accord well with the data

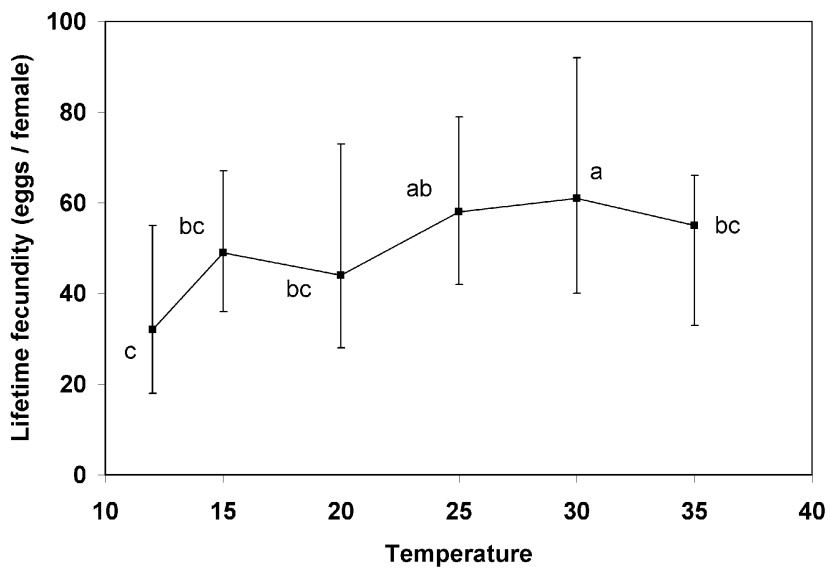

Fig. 6. The effect of temperature on the lifetime fecundity of the Trichogramma buesi females that parasitized hosts. Medians and quartiles are given. Symbols with different letters are significantly different $(p<0.05$, Tukey test of ranked data).

on other Trichogramma species (Lopez \& Morrison, 1980; Cônsoli \& Parra, 1995a; Kalyebi et al., 2006). Again, T. buesi seems to be relatively tolerant of high temperatures: in T. evanescens Westw., T. exiguum Pinto \& Platner and T. cordubensis Vargas \& Cabello no adults emerged when parasitized host eggs were kept at constant temperature of $35-36^{\circ} \mathrm{C}$ (Harrison et al., 1985; Cabello \& Vargas, 1988; Ayvaz et al., 2008).

The survival of larvae to the prepupal stage was also markedly lower at supra-optimal temperatures, but, in contrast to the survival from prepupa to adult, at suboptimal temperatures it was only slightly lower. Larvae seemed to be better adapted to low temperatures compared to pupae, non-diapausing prepupae and pharate adults. This difference, as far as we know, has not been previously recorded for Trichogramma species. The reason for it may be that under natural conditions in late autumn the diapause-oriented larvae often develop at temperatures close to the lower threshold, while the prepupae reactivated after winter diapause resume development at high temperatures.

Earlier, it was repeatedly shown that within the thermal tolerance range adult longevity of Trichogramma and other insects decreases with increasing temperature (Harrison et al., 1985; Cabello \& Vargas, 1988; Cônsoli \& Parra, 1995b; McDougall \& Mills, 1997; Schöller \& Hassan, 2001; Hansen \& Jensen, 2002; Abe \& Tahara, 2003; Ayvaz et al., 2008) and our experiments (Fig. 3) demonstrated that $T$. buesi is not an exception to this rule.

\section{Fecundity and number of mature eggs in ovaries}

Numerous authors have investigated the influence of temperature on Trichogramma fecundity. Although in some species the mean total number of parasitized hosts per female peaked at $20^{\circ} \mathrm{C}$ (e.g. Pavlik, 1992) in most the highest lifetime fecundity or the highest number of hosts parasitized within a certain period of time was recorded at ca $25^{\circ} \mathrm{C}$ (Pak \& Oatman, 1982; Harrison et al., 1985; Pak \& van Heiningen, 1985; Sorokina, 1987; Cabello \& Vargas, 1988; Cônsoli \& Parra, 1995b; Wang \& Ferro, 1998; Pratissoli \& Parra 2000; Carrière \& Boivin, 2001; 


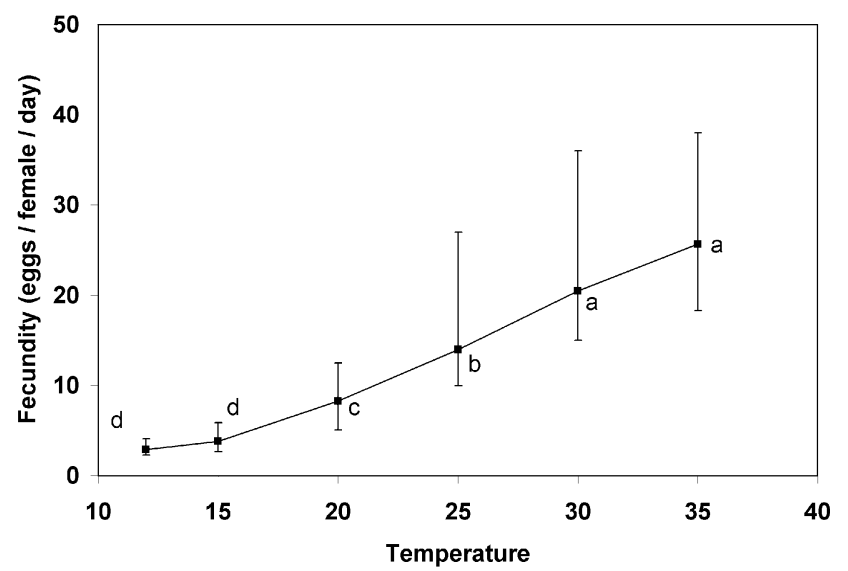

Fig. 7. The effect of temperature on the average daily rate of oviposition of the Trichogramma buesi females that parasitized hosts. Medians and quartiles are given. Symbols with different letters are significantly different $(\mathrm{p}<0.05$, Tukey test of ranked data).

Schöller \& Hassan, 2001; Hansen \& Jensen, 2002; Wang et al., 2004; Kalyebi et al., 2006; Reznik \& Vaghina, 2006; Ayvaz et al., 2008). Thus, our results accord with those of most earlier studies. Considering the results of the last experiment (Table 1) it is noteworthy that short pulses of high temperature did not significantly affect the fecundity of those females that parasitized.

Mean daily rate of oviposition showed a quite different temperature response, resembling that of the mean rate of development. Similarly, in Trichogramma turkestanica Meyer ( $=T$. euproctidis Girault) total lifetime fecundity was relatively stable, although the highest values were recorded at $25^{\circ} \mathrm{C}$, while mean daily parasitism (hosts/female/day) sharply increased from 0.2 at $15^{\circ} \mathrm{C}$ to 12.3 at $30^{\circ} \mathrm{C}$ (Hansen \& Jensen, 2002). Note that, in contrast to the rate of development, daily rate of oviposition still markedly increased with increase in temperature from $30^{\circ} \mathrm{C}$ to $35^{\circ} \mathrm{C}$ (comp. Figs 1 and 7).

In all treatments in the last experiment (Table 1) the number of mature eggs in the ovaries of 5 day old wasps was much higher than the 20-25 mature eggs in freshly emerged females of T. buesi (Reznik \& Vaghina, 2007b). In addition, under a thermorhythm it was slightly higher than at constant temperatures. Such a stimulating effect of alternating temperatures on the rate of egg maturation is recorded for various insect species (Beck, 1983; Ratte, 1985). Noteworthy is the observation that parasitizing females had markedly fewer mature eggs in their ovaries than females that delayed oviposition. These data, once again, demonstrate that contrary to the widely accepted assumption (Minkenberg et al., 1992; Barton Browne, 1993) "ovipositional drive" in Trichogramma wasps was not directly determined by "egg load".

\section{Total percentage of parasitizing females and duration} of the pre-oviposition period

The last review (Schmidt, 1994) of the subject concluded that Trichogramma females are active over a temperature range between $10^{\circ} \mathrm{C}$ and $35^{\circ} \mathrm{C}$. Our pilot tests showed that at $10^{\circ} \mathrm{C}$, as at $40^{\circ} \mathrm{C}, T$. buesi females did not parasitize. Certain other congeneric wasps parasitize host eggs even at $8-9^{\circ} \mathrm{C}$ (Keller, 1986; Rundle \& Hoffmann, 2003 ) but $T$. buesi, as repeatedly noted above, is a comparatively thermophilic species. Its lower temperature threshold for oviposition (between $10^{\circ} \mathrm{C}$ and $12^{\circ} \mathrm{C}$ ) was almost equal or only slightly higher than that for preimaginal development (ca $\left.10^{\circ} \mathrm{C}\right)$. In $T$. turkestanica $(=T$. euproctidis) the activity (walking) threshold was also rather close to the lower developmental threshold (Hansen, 2000), while e.g. in the leafminer parasitoid Gronotoma micromorpha (Perkins) studied by Abe \& Tahara (2003) the lower threshold for oviposition (ca $18^{\circ} \mathrm{C}$ ) was markedly higher than the lower developmental threshold $\left(11.7^{\circ} \mathrm{C}\right)$.

Earlier, it was shown that the maximum percentage of parasitizing T. embryophagum Htg. females is recorded at $20-25^{\circ} \mathrm{C}$ and significantly decreases towards the two limits of its thermal tolerance range (Sorokina, 1987). Similar results are reported for Trichogramma pretiosum Riley (Carrière \& Boivin, 2001) and the egg-larval parasitoid Chelonus oculator (F.) (García-Martín et al., 2008). In $T$. buesi cumulative percentage of parasitizing females (Fig. 5) was also highest at $25-30^{\circ} \mathrm{C}$. For several Trichogramma species only an increase in the percentage of parasitizing females with increase in temperature is reported (Pak \& van Heiningen, 1985; Basso et al., 1998; Reznik \& Vaghina, 2006). In contrast, non-parasitizing $T$. turkestanica $(=T$. euproctidis) females were recorded more often at $25-30^{\circ} \mathrm{C}$ than at $15-20^{\circ} \mathrm{C}$ (Hansen \& Jensen, 2002). These differences may depend on both Trichogramma species and temperature range studied.

Results of the last experiment (Table 1) seem to be new and quite unexpected. It is well known that thermorhythms often cause an increase in insect survival, fecundity etc. (Beck, 1983; Ratte, 1985). Such effects are also recorded for other Trichogramma species (e.g. Cônsoli \& Parra, 1995a). However, the effect of thermoperiod on the percentage of $T$. buesi females ovipositing revealed a very sharp, almost irreversible response, which was strongly dependent on the position of the thermophase in the photoperiod, which was earlier revealed only in the regulation of daily and seasonal cycles (Tauber et al., 1986; Zaslavski, 1988; Danks, 2003). Earlier (Reznik et al., 2001, 2003) we suggested that induction of parasitization, as of diapause or active development, is based on neuro-endocrine mechanisms. However, the similarity to the response to alternating temperatures seems to be superficial based on two features: (1) the interaction between light and temperature in the induction of parasitization and (2) the stability of the "parasitization state".

First, in our recent paper (Reznik et al., 2009) it is suggested that although Trichogramma females can parasitize in the dark, the beginning of parasitization (parasitization of the first host egg) practically always occurred during the photophase. It is known that a pulse of high temperature often produces the same effect as switching lights on (Tauber et al., 1986; Zaslavski, 1988; Danks, 2003). In particular, this effect can influence Trichogramma circadian cycles (Reznik et al., 1998). In the 
present study, however, a short term temperature increase induced parasitization only when applied during the light period.

Second, it is well documented that Trichogramma females that parasitize eggs of a given host species tend to continue parasitize eggs in stable conditions (Reznik et al., 2001, 2003), even after a temperature decrease (Reznik \& Vaghina, 2006). In an earlier attempt (Reznik \& Vaghina, 2006) to induce stable parasitization, T. principium females were kept at $25^{\circ} \mathrm{C}$ for $1-2$ days. In the present study (Table 1) the stable effect was induced in $T$. buesi by two short-term pulses of high temperature.

In most earlier studies on the effect of temperature on the percentage of Trichogramma females parasitizing, the period of observation was not longer than $24 \mathrm{~h}$ (e.g. Pak \& van Heiningen, 1985; Pavlik, 1992; Basso et al., 1998; Carrière \& Boivin, 2001) or the females were not fed during the experiment, which naturally limited the duration of the study (e.g. Sorokina, 1987). This is why delayed parasitization was often not recorded.

However, Orphanides \& Gonzalez (1970) demonstrate that the mean pre-parasitization period of $T$. pretiosum females ranged from several hours to several days, and is negatively correlated with temperature. In experiments conducted by Pak \& van Heiningen (1985) the average percentage of Trichogramma females that started to parasitize during a $24 \mathrm{~h}$ long exposure was much higher than during a $2 \mathrm{~h}$ long exposure, suggesting delayed parasitization. The increase in the rate of induction of parasitization revealed in the present study (Fig. 4) was similar to that described for T. principium (Reznik \& Vaghina, 2006) although a wider range of temperatures were analyzed here than previously. Note that the rate of induction markedly increased as temperature increased from 30 to $35^{\circ} \mathrm{C}$, although $35^{\circ} \mathrm{C}$ was obviously supra-optimal for $T$. buesi pre-emergence survival, cumulative percentage of ovipositing females and lifetime fecundity. Similarly, in T. brassicae Bezdenko walking speed and walking activity increases with temperature up to $35^{\circ} \mathrm{C}$ (Suverkropp et al., 2001).

We conclude that the first two of our hypotheses were supported by the experimental data. First, the maximum cumulative percentage of parasitizing females, preemergence survival and lifetime fecundity were recorded at temperatures of $25-30^{\circ} \mathrm{C}$, which is close to the middle of this species temperature tolerance range. Second, in contrast, the rate of induction of parasitization, the rate of preimaginal development and number of eggs laid each day increased up to $35^{\circ} \mathrm{C}$, which is close to the upper limit of temperature tolerance. As for the third hypothesis, the reaction to alternating temperatures was unexpectedly sharp: the percentage of females that started to parasitize under a thermoperiod was almost the same as that at a constant high temperature, which could be explained by the stability of the parasitization state.

Thus, the temperature dependence of ethogenesis was shown to be similar to that of morphogenesis, although ethological ontogenesis seemed to be much more variable, which hampers the modelling of this depend- ence. A similar conclusion was reached in a recent study of the effect of photoperiod on parasitization by Trichogramma principium (Reznik \& Vaghina, 2007a).

ACKNOWLEDGEMENTS. We are grateful to T.Ya. Umarova for rearing the insects and E.S. Sugonyaev for identifying the Trichogramma. We thank two anonymous reviewers for their valuable comments on an earlier version of the manuscript. This study was partly supported by the Programme "Biological Resources of Russia: Fundamental Bases of Rational Use" of the Department of Biological Sciences of Russian Academy of Sciences and by the State contract "Unique collections of Zoological Institute RAS” (UFK ZIN, N 2-2.20).

\section{REFERENCES}

ABE Y. \& TAHARA M. 2003: Daily progeny production and thermal influence on development and adult longevity of the leafminer parasitoid, Gronotoma micromorpha (Hym., Eucoilidae). J. Appl. Entomol. 127: 477-480.

Ayvaz A., Karasu E., Karabörklü S. \& Tunçbilek A.S. 2008: Effects of cold storage, rearing temperature, parasitoid age and irradiation on the performance of Trichogramma evanescens Westwood (Hymenoptera: Trichogrammatidae). $J$. Stored Prod. Res. 44: 232-240.

Barton Browne L. 1993: Physiologically induced changes in resource-oriented behavior. Annu. Rev. Entomol. 38: 1-25.

Basso C., Grille G., Pompanon F., Allemand R. \& Pintureau B. 1998: Comparacion de los caracteres biológicos y etológicos de Trichogramma pretiosum y de T. exiguum (Hymenoptera: Trichogrammatidae). Rev. Chil. Entomol. 25: 45-53.

BeCK S.D. 1983: Insect thermoperiodism. Annu. Rev. Entomol. 28: 91-108.

Bennett D.M., Reynolds K.T., Thomson L.J. \& Hoffmann A.A. 2002: Individual level trade-offs and artifacts in the egg parasitoid Trichogramma carverae (Hymenoptera, Trichogrammatidae). Ann. Entomol. Soc. Am. 95: 695-700.

Brière J.F., Pracros P., Le Roux A.-Y. \& Pierre J.S. 1999: A novel rate model of temperature-dependent development for arthropods. Environ. Entomol. 28: 22-29.

Butler G.D. \& Lopez J.D. 1980: Trichogramma pretiosum: development in two hosts in relation to constant and fluctuating temperatures. Ann. Entomol. Soc. Am. 73: 671-673.

Cabello T. \& Vargas P. 1988: The effect of temperature on the bionomics of Trichogramma cordubensis (Hym.: Trichogrammatidae). Coll. INRA 43: 155-164.

CARrière Y. \& Boivin G. 2001: Constrains of the evolution of thermal sensitivity of foraging in Trichogramma: genetic trade-offs and plasticity in maternal selection. Am. Natur. 157: 570-781.

CôNSOLI F.L. \& PARRa J.R.P. 1995a: Effect of constant and alternating temperatures on Trichogramma galloi Zucchi biology. I. Development and thermal requirements. J. Appl. Entomol. 119: 415-419.

Cônsoli F.L. \& Parra J.R.P. 1995b: Effect of constant and alternating temperatures on Trichogramma galloi Zucchi biology. II. Parasitism capacity and longevity. J. Appl. Entomol. 119: $667-670$.

DANKS H.V. 2003: Studying insect photoperiodism and rhythmicity: Components, approaches and lessons. Eur. J. Entomol. 100: 209-221.

Doyon J. \& Borvin G. 2005: The effect of development time on the fitness of female Trichogramma evanescens. J. Insect Sci. 5: 4 (insectscience.org/5.4). 
Foerster M.R. \& Foerster L.A. 2009: Effects of temperature on the immature development and emergence of five species of Trichogramma. BioControl 54: 445-450.

García-Martín M., Gámez M., Torres-Ruiz A. \& Cabello T. 2008: Functional response of Chelonus oculator (Hymenoptera: Braconidae) to temperature, and its consequences to parasitism. Commun. Ecol. 9: 45-51.

HANSEN L.S. 2000: Development time and activity threshold of Trichogramma turkestanica on Ephestia kuehniella in relation to temperature. Entomol. Exp. Appl. 96: 185-188.

Hansen L.S. \& Jensen K.M. 2002: Effect of temperature on parasitism and host-feeding of Trichogramma turkestanica (Hymenoptera: Trichogrammatidae) on Ephesia kuehniella (Lepidoptera: Pyralidae). J. Econ. Entomol. 95: 50-56.

HARRISON W.W., KING E.G. \& OUZTS J.D. 1985: Development of Trichogramma exiguum and T. pretiosum at five temperature regimes. Environ. Entomol. 14: 118-121.

Hoffmann M.P., Ode P.R., Walker D.L., Gardner J., van Nounuys S. \& Shelton A.M. 2001: Performance of Trichogramma ostriniae (Hymenoptera: Trichogrammatidae) reared on factitious hosts, including the target host, Ostrinia nubilalis (Lepidoptera: Crambidae). Biol. Contr. 21: 1-10.

HonĚK A. \& KoCOUREK F. 1990: Temperature and development time in insects: a general relationship between thermal constants. Zool. Jb. Syst. 117: 401-439.

JARJeEs E.A. \& MerritT D.J. 2002: Development of Trichogramma australicum Girault (Hymenoptera: Trichogrammatidae) in Helicoverpa (Lepidoptera: Noctuidae) host eggs. Austral. J. Entomol. 41: 310-315.

Kalyebi A., Overholt W.A., Schulthess F., Mueke J.M. \& Sithanantham S. 2006: The effect of temperature and humidity on the bionomics of six African egg parasitoids (Hymenoptera, Trichogrammatidae). Bull. Entomol. Res. 96: 305-314.

Keller M.A. 1986: Overwintering by Trichogramma exiguum in North Carolina. Environ. Entomol. 15: 659-661.

LOPEZ J.D. \& MORRISON R.K. 1980: Effects of high temperatures on Trichogramma pretiosum programmed for field release. $J$. Econ. Entomol. 73: 667-670.

McDougall S.J. \& Mills N.J. 1997: The influence of hosts, temperature and food sources on the longevity of Trichogramma platneri. Entomol. Exp. Appl. 83: 195-203.

Mertz B.P., Fleischer S.J., CAlvin D.D. \& Ridgway R.L. 1995: Field assessment of Trichogramma brassicae (Hymenoptera: Trichogrammatidae) and Bacillus thuringiensis for control of Ostrinia nubilalis (Lepidoptera: Pyralidae) in sweet corn. $J$. Econ. Entomol. 88: 1616-1625.

Minkenberg O.P.J.M., Tatar M. \& Rosenheim J.A. 1992: Egg load as a major source of variability in insect foraging and oviposition behavior. Oikos 65: 134-142.

OrPhanides G.M. \& Gonzalez D. 1970: Importance of light in the biology of Trichogramma pretiosum. Ann. Entomol. Soc. Am. 63: 1734-1740.

PAK G.A. \& van Heiningen T.G. 1985: Behavioural variations among strains of Trichogramma spp.: Adaptability to field temperature conditions. Entomol. Exp. Appl. 38: 3-13.

PAK G.A. \& OATMAN E.R. 1982: Comparative life table, behavior and competition studies of Trichogramma brevicapillum and T. pretiosum. Entomol. Exp. Appl. 32: 68-79.

PAVLIK J. 1992: The effect of temperature on parasitization activity in Trichogramma spp. (Hymenoptera, Trichogrammatidae). Zool. Jb. Physiol. 96: 417-425.

PAVLIK J. 1993: Variability in the host acceptance of European corn borer, Ostrinia nubilalis Hbn. (Lepidoptera, Pyralidae) in strains of the egg parasitoid Trichogramma spp. (Hymenoptera, Trichogrammatidae). J. Appl. Entomol. 115: 77-84.

Pratissoli D. \& Parra J.R.P. 2000: Fertility life table of Trichogramma pretiosum (Hym., Trichogrammatidae) in eggs of Tuta absoluta and Phthorimaea operculella (Lep., Gelechiidae) at different temperatures. J. Appl. Entomol. 124: 339-342.

RATTE H.T. 1985: Temperature and insect development. In Hoffmann K.H. (ed.): Environmental Physiology and Biochemistry of Insects. Springer, Berlin, pp. 33-66.

ReZniK S.YA. \& VAGHINA N.P. 2006: Temperature effects on induction of parasitization by females of Trichogramma principium (Hymenoptera, Trichogrammatidae). Entomol. Rev. 86: $133-138$.

REZNIK S.YA. \& VAGHINA N.P. 2007a: Effect of photoperiod on parasitization by Trichogramma principium (Hymenoptera: Trichogrammatidae). Eur. J. Entomol. 104: 705-713.

Reznik S.Ya. \& Vaghina N.P. 2007b: Effect of experience on response of Trichogramma buesi Voeg. and T. principium Sug. et Sor. (Hymenoptera, Trichogrammatidae) females to different ages of host eggs. Entomol. Rev. 87: 1-10.

Reznik S.Ya., Zinov'eva K.B., Umarova T.Ya. \& Zaslavski V.A. 1998: Dependence of eclosion rhythm on photoperiod and thermoperiod in species of the genus Trichogramma (Hymenoptera, Trichogrammatidae). Entomol. Rev. 78: 13-19.

RezniK S.YA., VoINovich N.D. \& Umarova T.Ya. 2001: Longterm egg retention and parasitization in Trichogramma principium (Hymenoptera, Trichogrammatidae). J. Appl. Entomol. 125: 169-175.

Reznik S.Ya., Umarova T.Ya. \& Voinovich N.D. 2003: Egg retention in Trichogramma (Hymenoptera: Chalcidoidea: Trichogrammatidae): Learning or diapause? Acta Soc. Zool. Bohem. 67: 25-33.

Reznik S.Ya., Voinovich N.D. \& Karpova S.G. 2009: Daily rhythms in parasitization of the Angoumois grain moth Sitotroga cerealella Oliv. (Lepidoptera, Gelechiidae) eggs by the egg parasitoid Trichogramma principium Sug. et Sor. (Hymenoptera, Trichogrammatidae) females. Entomol. Rev. 89: 5-15.

RichaRdS C.S. \& VilLet M.H. 2008: Factors affecting accuracy and precision of thermal summation models of insect development used to estimate post-mortem intervals. Int. J. Legal Med. 122: 401-408.

RundLe B.J. \& Hoffmann A.A. 2003: Overwintering of Trichogramma funiculatum Carver (Hymenoptera: Trichogrammatidae) under semi-natural conditions. Environ. Entomol. 32: 290-298.

SchmidT J.M. 1994: Host recognition and acceptance by Trichogramma. In Wajnberg E. \& Hassan S.A. (eds): Biological Control with Egg Parasitoids. CAB International, Wallingford, pp. 165-199.

SCHÖlleR M. \& Hassan S.A. 2001: Comparative biology and life tables of Trichogramma evanescens and T. cacoeciae with Ephestia elutella as host at four constant temperatures. Entomol. Exp. Appl. 98: 35-40.

SмITH S.M. 1996: Biological control with Trichogramma: advances, successes, and potential of their use. Annu. Rev. Entomol. 41: 375-406.

SoROKINA A.P. 1987: Biological and morphological substantiation of the specific distinctness of Trichogramma telengae sp.n. (Hymenoptera, Trichogrammatidae). Entomol. Obozr. 66: 32-46 [in Russian].

Suverkropp B.P., Bigler F. \& van Lenteren J.C. 2001: Temperature influences walking speed and walking activity of Tri- 
chogramma brassicae (Hymenoptera: Trichogrammatidae). J. Appl. Entomol. 125: 303-307.

Tauber M.J., Tauber C.A. \& Masaki S. 1986: Seasonal Adaptations of Insects. Oxford University Press, Oxford, $412 \mathrm{pp}$.

Voegele J., Pizzol J. \& Babi A. 1988: The overwintering of some Trichogramma species. Coll. INRA 43: 275-282.

WANG B. \& FERRo D.N. 1998: Functional responses of Trichogramma ostriniae (Hymenoptera: Trichogrammatidae) to Ostrinia nubilalis (Lepidoptera, Pyralidae) under laboratory and field conditions. Environ. Entomol. 27: 752-758.

Wang B., Ferro D.N., Wu J. \& Wang S. 2004: Temperaturedependent development and oviposition behavior of Tricho- gramma ostriniae (Hymenoptera: Trichogrammatidae), a potential biological control agent for the European corn borer (Lepidoptera: Crambidae). Environ. Entomol. 33: 787-793.

Withers T.M., Barton Browne L. \& Stanley J. 2000. How time-dependent processes can affect the outcome of assays. In Van Driesche R., Heard T., McClay A. \& Reardon R. (eds): Host Specificity Testing of Exotic Arthropod Biological Control Agents: The Biological Basis for Improvement in Safety. USDA Forest Service, Morgantown, WV, pp. 27-42.

Zaslavski V.A. 1988: Insect Development: Photoperiodic and Temperature Control. Springer, New York, Berlin, 187 pp.

Received March 4, 2009; revised and accepted May 6, 2009 